\title{
Where is VEGF in the body? A meta-analysis of VEGF distribution in cancer
}

\author{
C Kut', F Mac Gabhann ${ }^{*, 1}$ and AS Popel' \\ 'Department of Biomedical Engineering, Johns Hopkins University School of Medicine, Baltimore, MD 2 I 205, USA
}

\begin{abstract}
Vascular endothelial growth factor (VEGF) is a major target for the inhibition of tumour vascularisation and the treatment of human cancer. Many tumours produce large quantities of VEGF, and as a result, diagnosis and prognosis of cancer may be predicted by measuring changes in VEGF concentrations in blood. In blood, the VEGF may be located in the plasma, or in the blood-borne cells and formed elements, in particular, platelets and leukocytes. In this study, we collate the measurements of VEGF in platelets, leukocytes, plasma and serum for breast, prostate, colorectal and other cancers. In addition, we analysed the concentration of VEGF in tumour tissue itself, as well as for other tissues in the human body. Although the concentration of VEGF in tumours is high, the size of tumours is small compared to other tissues, in particular, skeletal muscle. Thus, the total quantity of VEGF in tumours and in blood is small compared to the quantity in muscles. This large reservoir of VEGF may have important implications for the treatment of cancer.
\end{abstract}

British Journal of Cancer (2007) 97, 978-985. doi:10.1038/sj.bjc.6603923 www.bjcancer.com

Published online 2 October 2007

(c) 2007 Cancer Research UK

Keywords: breast cancer; colorectal cancer; prostate cancer; serum; platelets; leukocytes

Angiogenesis, the development of new blood vessels from preexisting vasculature, has important roles in growth and development, wound healing and tumorigenesis. The vascular endothelial growth factor (VEGF) family of proteins has a pivotal role in regulating tumour angiogenesis (Shibuya and Claesson-Welsh, 2006).

Vascular endothelial growth factor stimulates cell survival, migration and differentiation. It induces neovascularisation, and is required for the establishment of haematopoiesis; in malignant tumours, VEGF supports development of tumour vessels, which may lead to increased vascular permeability, and is shown to have a correlation with cancer prognosis and diagnosis (Folkman, 1995; Hormbrey et al, 2002).

A marked increase in VEGF levels has been observed in various types of cancer including anal carcinoma (Kusumanto et al, 2003), lymphoma (Salven et al, 1999a), lung cancer (Salgado et al, 1999; Yanagawa et al, 1999; Matsuyama et al, 2000; Kishiro et al, 2002), gastric carcinoma (Hyodo et al, 1998; Kraft et al, 1999; Yoshikawa et al, 2000), ovarian cancer (Hyodo et al, 1998; Tempfer et al, 1998; Kraft et al, 1999; Yoshikawa et al, 2000), renal cell carcinoma (Dosquet et al, 1997; Sato et al, 1999; Jacobsen et al, 2002; Ljungberg et al, 2003), brain tumour (Stockhammer et al, 2000), hepatocellular carcinoma (Poon et al, 2001), breast cancer (Bando et al, 2005; O'Riain et al, 2005), prostate cancer (Kaushal et al, 2005; Li et al, 2005) and colorectal cancer (Haraguchi et al, 2002; Karayiannakis et al, 2002; Werther et al, 2003). Of these, the last three are most extensively studied.

*Correspondence: F Mac Gabhann; E-mail: feilim@jhu.edu

Received 2 March 2007; revised 19 June 2007; accepted 12 July 2007; published online 2 October 2007
Both breast and prostate cancer are commonly diagnosed malignancies, and are among the top leading causes of death responsible for 15 and $10 \%$ of cancer deaths in women and men, respectively in 2005 (Uzzan et al, 2004; Jemal et al, 2005). Colorectal cancer is responsible for $10 \%$ of all cancer deaths in 2005 (Jemal et al, 2005). For all three cancer types, significant correlations between VEGF and the extent of tumour vascularisation, tumour stages and metastasis have been reported (Duque et al, 1999; Gasparini, 2000; Karayiannakis et al, 2002). In addition, it is reported that the status of oestrogen (ER) and progesterone $(\mathrm{PgR})$ receptors may have direct correlation with VEGF level in breast cancer patients (Duque et al, 1999; Gasparini, 2000; Eccles, 2001; Karayiannakis et al, 2002). In recent years, VEGF has been considered a significant indicator of cancer, and blood VEGF levels are often used to estimate the degree of tumour development.

However, the debate is still on as to the origin and location of VEGF. Serum, plasma and whole blood have been commonly used to determine VEGF levels in the body, but it is not clear which measurement can provide the best prognostic information. Plasma is the free circulating, liquid component of blood, in which bloodformed elements are suspended. Serum is plasma with all coagulation factors removed, and is obtained by clotting the blood before centrifugation. Because coagulation results in the release of VEGF from platelets, serum VEGF concentration counts both plasma VEGF and platelet-held VEGF.

A number of studies report correlation between platelet counts and serum VEGF (Werther et al, 2002b; Caine et al, 2004), and higher serum VEGF levels per platelet in cancer (Salven et al, 1999a; Kusumanto et al, 2003). The importance of platelet-derived VEGF in cancer may be due to VEGF released upon thrombin activation by platelets, with VEGF inducing vascular permeability 
and in doing so further promoting coagulation (Mohle et al, 1997; Verheul and Pinedo, 1998). Other studies suggest that leukocytes are more important sources of VEGF in cancer patients. A similar mechanism concerning permeability and thrombin activation has been postulated to account for the leukocyte-VEGF interaction (Mohle et al, 1997; Salven et al, 1999a; Kusumanto et al, 2003). To determine platelet VEGF, values for platelet-rich plasma (PRP) and platelet-poor plasma (PPP) have been compared; for leukocytes, the values from a peripheral blood mononuclear cell suspension (PBMNC) have been obtained.

Studies on VEGF levels in urine (Bok et al, 2001), pleural effusion (Kraft et al, 1999; Thickett et al, 1999; Yanagawa et al, 1999; Kishiro et al, 2002; Toi et al, 2002), tumour cytosol (Obermair et al, 1997; Eppenberger et al, 1998; Baker et al, 2000; Broll et al, 2001; Foekens et al, 2001; Haraguchi et al, 2002; Toi et al, 2002; Manders et al, 2003; Desruisseau et al, 2004; Bando et al, 2005), tumour cyst fluid (Stockhammer et al, 2000) and other body fluids are available. However, most do not have a basis of comparison, as they report only the VEGF levels in cancer patients, but no control equivalent in healthy volunteers. It may be possible to compare some of these to values in healthy individuals from other studies.

The inhibition of VEGF expression and signalling in tumours is a promising therapeutic strategy. Tumour-induced angiogenesis is largely dependent on VEGF, and studies have demonstrated that anti-VEGF antibodies successfully inhibit both angiogenesis and tumour growth (Eatock et al, 2000). The first anti-VEGF drug, bevacizumab, was approved by Food and Drug Administration in 2004. In all phase trials, the drug was reported to be well-tolerated, and increased the response and survival rates of patients (Tortora et al, 2004).

In contrast to VEGF inhibition in tumours and other diseases, administration of additional VEGF could potentially treat disorders that result in restricted or limited blood supply. For example, it may be a therapeutic agent for chronic limb ischaemia, which is often caused by obstructive atherosclerosis and has a high mortality rate; other potential therapeutic applications include the treatment of coronary insufficiency and restenosis (Ferrara and Davis-Smyth, 1997).

Understanding the distribution of VEGF in human body is vital to the prognosis and treatment of cancer and other disorders. It is especially important for designing and understanding anti-VEGF therapeutics. However, important variations across studies, including methods of sample collection, patient selection, measurement units, statistical analysis and data interpretation, make it difficult to obtain a global view of VEGF distribution. To our knowledge, there has been no comprehensive review of the literature that elucidates the relative concentrations of VEGF in such body compartments as blood, normal tissues and organs, and tumour, nor one that gives detailed overview of VEGF levels across various cancer types. The present study aims to review previously reported VEGF levels and summarise the results in the form of VEGF localisation to various body compartments. An additional motivation and aim of the present study is to provide a solid basis for quantitative, systems biology studies of the VEGF system in health and disease (Mac Gabhann and Popel, 2006; Mac Gabhann et al, 2006).

\section{METHODS}

\section{Publication selection}

Meta-analysis was based on an electronic literature search through Pubmed and Google Scholar. Key words used included: vascular endothelial growth factor; VEGF; cancer; breast; prostate; colorectal; serum; plasma; platelets; and leukocytes. Papers were also found through the references and citations of all the relevant studies. To be included in our meta-analysis, papers had to be in vivo studies, included in the Pubmed database, deal with cancer patients and present quantitative VEGF data. Studies with aberrant data (over a 10 -fold difference than those reported in other papers) were also excluded. Based on these criteria, 12 studies were excluded from our collection (Liu et al, 1999; Haggstrom et al, 2000; Bhujwalla et al, 2001; Feldman et al, 2001; George et al, 2001; Huss et al, 2001; Kelavkar et al, 2001; Calvo et al, 2002; Mabjeesh et al, 2003; Cianchi et al, 2004; Singh et al, 2004; May et al, 2005) (Supplementary Table S6).

\section{Information extraction}

The following items were extracted from each paper: type of cancer, sample size, location of VEGF measured, VEGF isoform studied, methodology of data collection, VEGF diagnosis, statistical format, platelet/leukocyte count and the mean or median value for both healthy and cancer VEGF concentration. If the paper presented VEGF data in several categories and failed to report an overall cancer VEGF value, data estimation (indicated by an asterisk * in Supplementary Tables S1-S4, online supplement) was performed taking the average of data in all categories. Our analysis was performed by comparing results from individual papers. We did not amend the statistical analyses used in each paper.

\section{Vascular endothelial growth factor measurement methods used}

Both plasma and serum have been commonly used to determine VEGF levels in the blood. From our reviewed literature, peripheral venous blood samples were drawn. To prepare plasma, blood samples were put in test tubes with an anticoagulant (either trisodium citrate or ethylenediaminetetraacetic acid). The test tubes were then left for $0-30 \mathrm{~min}$ before centrifugation, $1000-3000 \times \mathbf{g}$ at $4-21^{\circ} \mathrm{C}$ for $10-20 \mathrm{~min}$. To prepare serum, blood samples were put in sterile silicone-coated tubes without additive, or serum separator/clot activator test tubes. Blood samples were then allowed to clot for 30-120 min before centrifugation, $1000-3000 \times \mathbf{g}$ at $4-21^{\circ} \mathrm{C}$, for $7-15 \mathrm{~min}$ (one paper reported a centrifugation rate of $16000 \times \mathrm{g}$ ). Both plasma and serum samples were subsequently aliquoted and stored at -20 to $-80^{\circ} \mathrm{C}$ before assay.

To obtain tumour cytosol measurements, tumour tissues obtained during surgery were immediately frozen in liquid nitrogen. To prepare the samples, the tissue samples were diluted in a buffer. The tissues were then either homogenised with Ultra Terrex, pulverised with microdismembrator or diced with a scalpel. The homogenised tissue samples were then centrifuged at $800-105000 \times \mathrm{g}$, for $15-60 \mathrm{~min}$. The resulting supernatant (tumour cytosol) was then stored at -70 to $-80^{\circ} \mathrm{C}$ until analysis.

Enzyme-linked immunosorbent assay (ELISA) was the adopted assay type for $74 \%$ of the studies. Among those using ELISA, $40 \%$ obtained the assay kit from R\&D Systems, (Minneapolis, MN, USA). The remaining $60 \%$ used kits from 14 other different companies. Five other different assay types were also used, including quantitative sandwich enzyme immunoassay, enzyme immunoassay, chemiluminescence immunosorbent assay, human VEGF immunoassay quantigo kit and immunofluorometric assay.

\section{Data analysis}

The weighted average and s.d. of VEGF concentrations were evaluated in all cancer studies for various compartment of the body (serum, plasma, whole blood and tumour cytosol). Our calculations were based on the following equations:

$$
\begin{aligned}
& \text { Weighted average }\left(x_{\text {avg }}\right)=\sum\left(n_{\mathrm{i}} * x_{\mathrm{i}}\right) / \sum n_{\mathrm{i}} \\
& \text { Weighted standard deviation }=\sum n_{\mathrm{i}} *\left(x_{\mathrm{i}}-x_{\text {avg }}\right)^{2} / \sum n_{\mathrm{i}}
\end{aligned}
$$

$n_{\mathrm{i}}$ : number of subjects reported in each paper; $x_{\mathrm{i}}$, VEGF level reported in each paper. 
A two-sample, one-tailed Student's $t$-test was used. A probability of $<0.05$ was taken to be significant. The overall statistical metaanalysis is given in Table 1. In our meta-analyses, units were reported in $\mathrm{pg} \mathrm{ml}^{-1}$, $\mathrm{pg} \mathrm{mg}^{-1}$ protein, $\mathrm{pg} 10^{-6}$ cells, $10^{6}$ cells $\mathrm{ml}^{-1}$. Unit conversion was performed whenever necessary. Concentrations are rounded to whole numbers.

\section{RESULTS AND DISCUSSION}

\section{Study selection}

Our literature search identified 64 references containing quantitative information to be included in this analysis, including 19 breast cancer, 13 prostate cancer, 13 colorectal cancer and 19 other cancer studies. Details for each of these studies are given in Supplementary Table S1 for breast cancer (Yamamoto et al, 1996; Obermair et al, 1997; Salven et al, 1997, 1999b; Verheul et al, 1997; Eppenberger et al, 1998; Adams et al, 2000; Foekens et al, 2001; Heer et al, 2001; Colleoni et al, 2002; Toi et al, 2002; Caine et al, 2003; Manders et al, 2003; Desruisseau et al, 2004; Granato et al, 2004; Sancak et al, 2004; Zhao et al, 2004; Bando et al, 2005; O'Riain et al, 2005), Supplementary Table S2 for prostate cancer (Joseph et al, 1997; Salven et al, 1997; Bauer et al, 1999; Duque et al, 1999; Jones et al, 2000; Bok et al, 2001; Figg et al, 2001; Caine et al, 2003, 2004; Kohli et al, 2003; George et al, 2004; Kaushal et al, 2005; Li et al, 2005), Supplementary Table S3 for colorectal cancer (Dirix et al, 1996; Hyodo et al, 1998; Kumar et al, 1998; Baker et al, 2000; Chin et al, 2000; Davies et al, 2000; George et al, 2000; Broll et al, 2001; Haraguchi et al, 2002; Karayiannakis et al, 2002; Werther et al, 2002a, b, 2003) and Supplementary Table S4 for other cancers (Yeo et al, 1993; Dosquet et al, 1997; Hyodo et al, 1998; Tempfer et al, 1998; Viac et al, 1998; Kraft et al, 1999; Salgado et al, 1999; Sato et al, 1999; Thickett et al, 1999; Yanagawa et al, 1999; Salven et al, 1999a; Matsuyama et al, 2000; Stockhammer et al, 2000; Yoshikawa et al, 2000; Tabone et al, 2001; Jacobsen et al, 2002; Kishiro et al, 2002; Kusumanto et al, 2003; Ljungberg et al, 2003).

\section{Cancer studies and meta-analysis}

Breast cancer The main results on healthy and cancer VEGF levels are summarised in Supplementary Table S1 and Figures $1 \mathrm{~A}$ $2 \mathrm{~A}$ and $\mathrm{B}$. Serum VEGF levels in cancer patients appear to be about two times higher than those in healthy controls (range: $92-390 \mathrm{vs}$ 17-287 $\mathrm{pg} \mathrm{ml}^{-1}$ ). Plasma VEGF levels have a range of 37$310 \mathrm{pg} \mathrm{ml}^{-1}$ (cancer) vs $27-30 \mathrm{pg} \mathrm{ml}^{-1}$ (healthy). Tumour cytosol VEGF values range from 140 to $693 \mathrm{pg} \mathrm{mg}^{-1}$ protein, but there is no control equivalent in healthy subjects or other tissues in these studies. We will compare these values with measurements from other tissues reported in other studies.

The relationship between VEGF in cancer and expression of hormone receptors for oestrogen and progesterone was also examined. Serum values appear to be slightly higher for both positive ER and PgR status, although the difference does not appear to be significant (ER status: 75-271 (negative) vs 90$298 \mathrm{pg} \mathrm{ml}^{-1}$ (positive); PgR status: $75-141$ (negative) vs 89$187 \mathrm{pg} \mathrm{ml}^{-1}$ (positive)). However, both ER and PgR tumour cytosol values deviate from the above data, where ER-negative values are 1.5-2 times higher than ER-positive values $(360-700$ vs $180-$ $560 \mathrm{pg} \mathrm{mg}^{-1}$ protein) and PgR-negative values are 1.5 times higher than PgR-positive values (289-760 vs 212-510 $\mathrm{pg} \mathrm{mg}^{-1}$ protein).

Prostate cancer Results are summarised in Supplementary Table S2 and Figures 1B and 2B. Vascular endothelial growth factor level is 2-3 times higher in serum, and 3-10 times higher in plasma of cancer patients (serum: $129-323$ cancer vs $17-171 \mathrm{pg} \mathrm{ml}^{-1}$ (healthy); plasma: $32-730$ cancer $v s 13-61 \mathrm{pg} \mathrm{ml}^{-1}$ (healthy)).

Colorectal cancer Results are summarised in Supplementary Table S3 and Figures 1C, 2A and B. Both serum and plasma VEGF are about two times higher in cancer patients (serum: 66-563 cancer $v s 173-391 \mathrm{pg} \mathrm{ml}^{-1}$ (healthy); plasma: 19-211 cancer $v s 9-$ $126 \mathrm{pg} \mathrm{ml}^{-1}$ (healthy)). Whole blood values are relatively high (597-700 cancer vs $506 \mathrm{pg} \mathrm{ml}^{-1}$ (healthy)), although results may have been skewed with only two studies involved. Tumour cytosol values range from 189 to $984 \mathrm{pg} \mathrm{mg}^{-1}$ protein, which are approximately 1.5 times higher than those in breast cancer studies.

Other cancer types Results are summarised in Supplementary Table S4 and Figure 1D. When compared to healthy VEGF, cancer VEGF is elevated by approximately $2-4$ times for serum values, and by 2-6 times for plasma values (serum: 207-681 cancer vs $51-318 \mathrm{pg} \mathrm{ml}^{-1}$ (healthy); plasma: $23-137$ cancer $v s 9-26 \mathrm{pg} \mathrm{ml}^{-1}$ (healthy)). For whole blood VEGF, cancer values are again higher when compared to serum and plasma data (461-1435 cancer vs $298-301 \mathrm{pg} \mathrm{ml}^{-1}$ (healthy)).

Table I Weighted average VEGF of all cancer studies

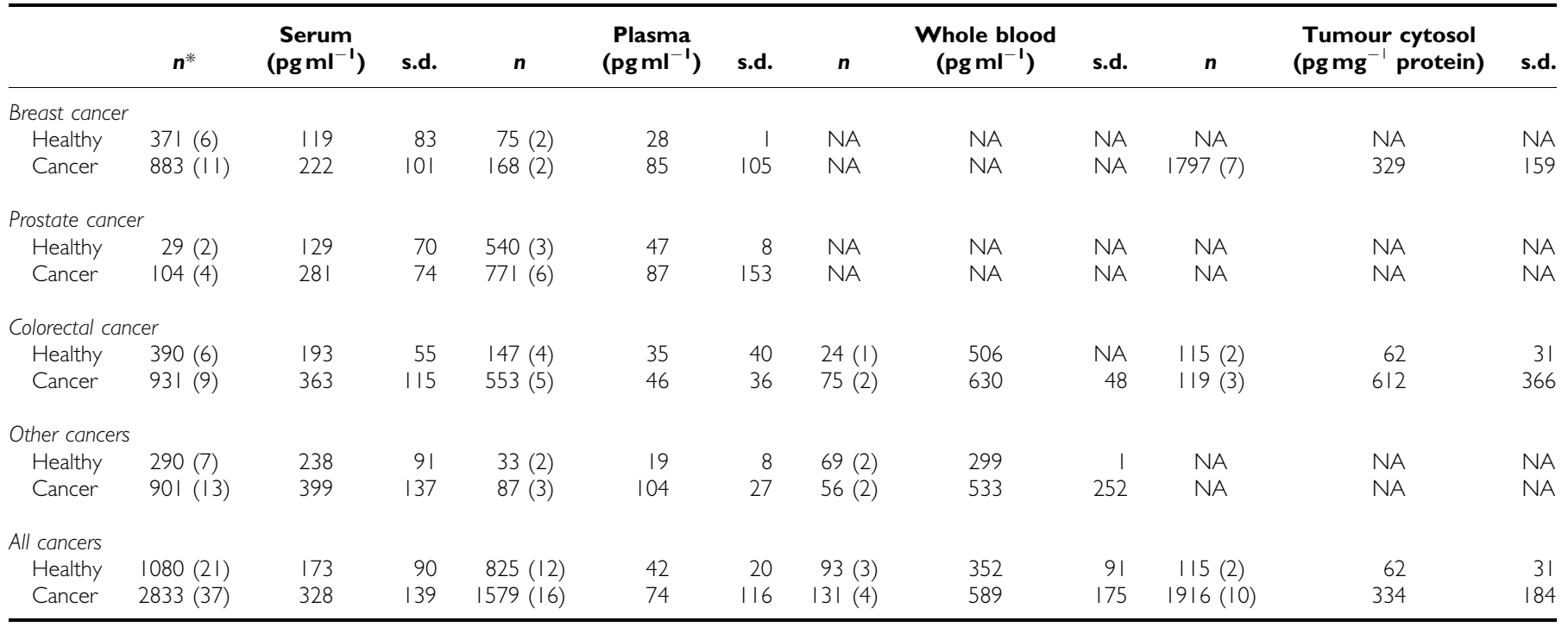

*Total number of patients (number of papers). Abbreviation: VEGF = vascular endothelial growth factor. 

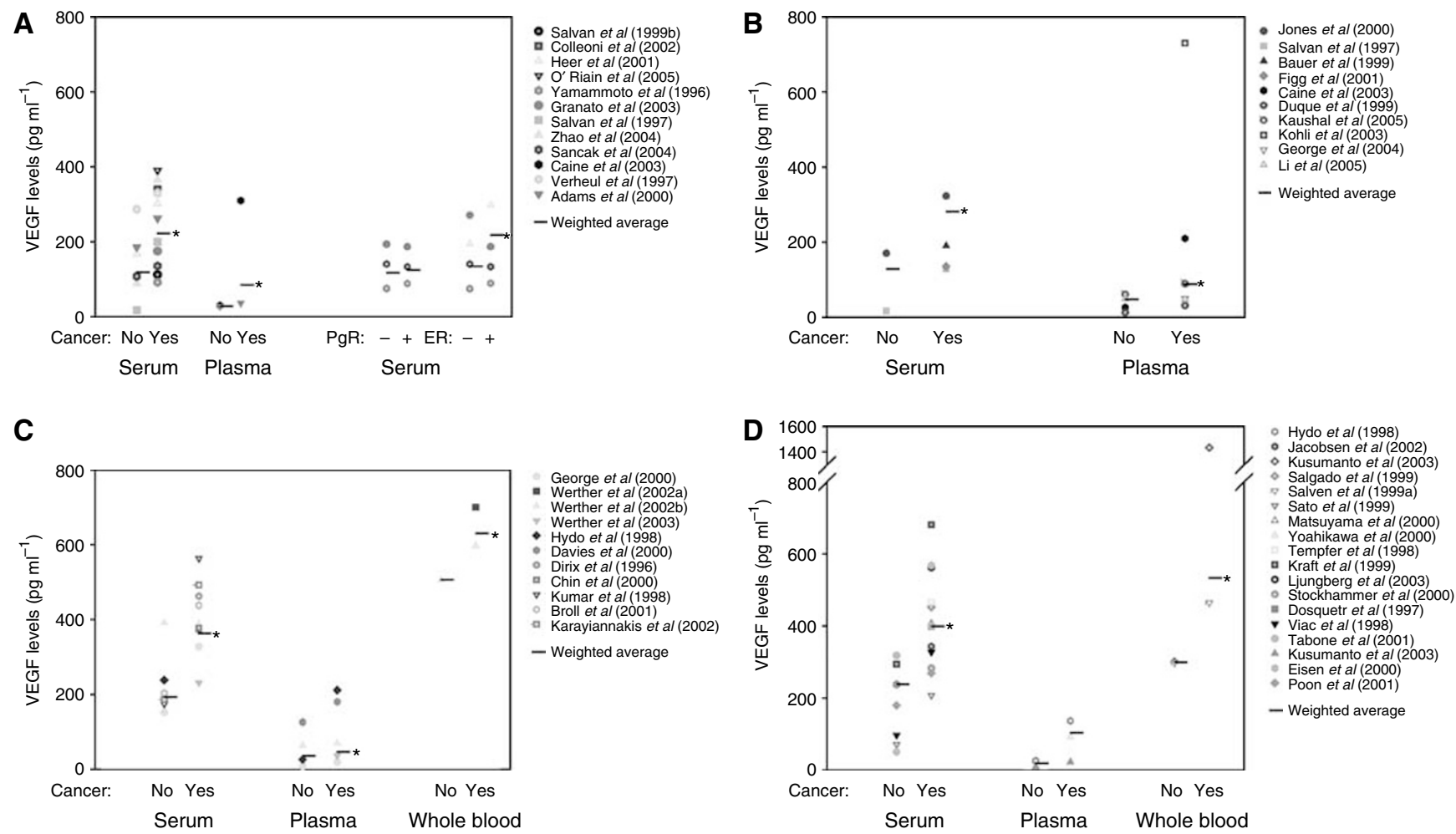

Figure I Vascular endothelial growth factor (VEGF) levels in the blood of cancer patients and healthy volunteers. (A) Breast cancer studies. (B) Prostate cancer studies. (C) Colorectal cancer studies. (D) Other cancer studies. Weighted average for VEGF values denoted by a bar in the graph. *P<0.00 I greater than healthy controls.
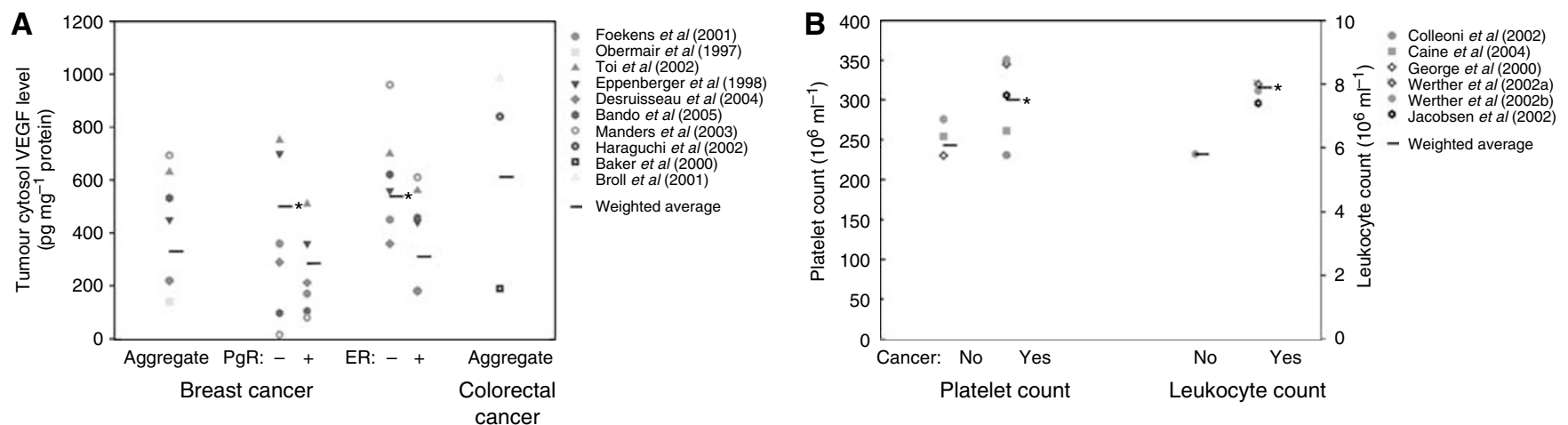

Figure 2 Intratumoural VEGF levels and platelet and leukocyte numbers. (A) Tumour cytosol VEGF levels. Colorectal tumour cytosol VEGF values are approximately 1.5 times higher than those in breast cancer studies. (B) Platelet count and leukocyte count in cancer studies. $* P<0.00$ I greater than healthy controls.

Summary Results are summarised in Table 1 and Figure $1 \mathrm{~A}-\mathrm{D}$. When compared to the ranges of healthy VEGF levels, reported cancer VEGF ranges are about twice as large. The ranges of reported healthy values of VEGF are mostly comparable. Within all groups, the weighted average of normal VEGF is lower than that of the cancer values. Between the groups, however, the average healthy VEGF can be comparable to cancer levels in other groups. For example, average healthy serum VEGF in the other cancer studies is slightly higher than average breast cancer serum VEGF (238 vs $222 \mathrm{pg} \mathrm{ml}^{-1}$ ).

\section{Compartmental analysis and data interpretation}

Blood compartment To evaluate VEGF distribution in the body, we combined all the studies and derived the average VEGF concentration for serum and plasma. To determine the total quantity of serum or plasma VEGF in the body, we multiplied concentrations by the total volume of serum or plasma, 2.26l, as explained below (Lentner et al, 1984). Based on this analysis, we evaluated the quantity of VEGF in serum to be 4.3 (healthy) and 4.4 (cancer) times higher than the quantity of VEGF in plasma. The results are summarised in Figure $3 \mathrm{~A}$ and $\mathrm{B}$.

Vascular endothelial growth factor evaluation for platelets is based on two types of measurements: plasma-corrected VEGF/ platelet values from Salven et al (1999b); George et al (2000); and PRP measurements from Kusumanto et al (2003) and Salven et al (1999a). We excluded reference Caine et al (2004) because the data reported was three orders of magnitude higher than those reported in other studies. Concentrations are calculated using volume of a platelet, $9 \mathrm{fl}$ (Lentner et al, 1984), and quantity is determined by 

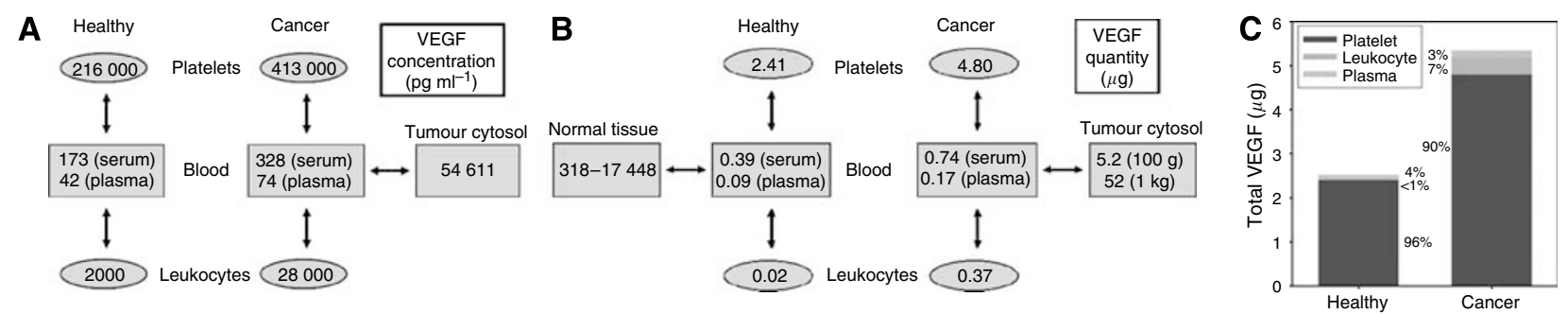

Figure 3 Vascular endothelial growth factor (VEGF) distribution in the body. (A) Concentrations of VEGF in the body. Average VEGF concentrations are recorded for platelets, leukocytes and the blood compartment for both healthy and control values. (B) Quantities of VEGF in the body. Average VEGF quantities are recorded for platelets, leukocytes and the blood compartment for both healthy and control values. (C) Comparison of blood VEGF quantities in healthy and cancer studies. Percentages of VEGF platelets, leukocytes and the blood compartment are evaluated.

multiplying the concentration by the total volume of platelets in the blood (cancer: $14.18 \mathrm{ml}$, healthy: $11.15 \mathrm{ml}$ ) (Lentner et al, 1984; Werther et al, 2002b). Results are summarised in Figure $3 \mathrm{~A}$ and $\mathrm{B}$. Total quantity of VEGF in platelets is 6.5 times than that in serum, and 28.2 times higher than that in plasma for cancer patients.

Vascular endothelial growth factor is sequestered in the alpha granules of platelets at a high concentration. It has been suggested that platelets might recycle the VEGF they have scavenged, since the VEGF concentration increases in platelets over time for as long as the VEGF source is present (Folkman, 2007). The mechanisms underlying the VEGF sequestration, however, are not well established. Further research is necessary to determine how platelets contribute to the VEGF upregulation in cancer.

Leukocyte VEGF values are determined using PBMNC values from Salven et al (1999a). We took the average of granulocyte, lymphocyte and monocytes volumes, $383 \mathrm{fl}$ per cell (Lentner et al, 1984). We also calculated the total leukocyte volume in blood (cancer: $13.41 \mathrm{ml}$, healthy: $9.97 \mathrm{ml}$ ) (Lentner et al, 1984; Werther et al, 2002b). Results are shown in Figure 3A and B. We observe a low quantity of healthy leukocyte VEGF when compared to plasma, serum and platelet levels. However, the difference between healthy and cancer quantities is the highest. The quantity of VEGF in leukocytes in cancer is 18.5 times higher than that in healthy, which is 10 times the increase in plasma, serum or platelet VEGF in cancer.

Tumour compartment We evaluated the average VEGF level in tumour cytosol from the collected data in units of $\mathrm{pg} \mathrm{mg}^{-1}$ protein. Concentration $\left(\mathrm{pg} \mathrm{ml}^{-1}\right.$ ) was estimated using a protein mass ratio of $160 \mathrm{mg}^{\text {protein }} \mathrm{g}^{-1}$ fat-free tissue and tissue density of $1.06 \mathrm{~g}$ tissue $\mathrm{ml}^{-1}$ (Lentner et al, 1981). We calculated the total quantity of VEGF based on 100 and $1000 \mathrm{~g}$ tumours. Results are summarised in Figure 3A and B.

We observe that the quantity of VEGF in the tumours is 7-70 times higher than the quantity in serum, 31-306 times higher than plasma quantity, 1.1-10.8 times higher than platelet quantity and 14-141 times higher than leukocyte quantity. This indicates that tumour tissue is a significant source and reservoir for VEGF in a cancer patient.

Vascular endothelial growth factor content of normal tissues There is no standard control for tumour cytosol VEGF levels. Vascular endothelial growth factor levels in the normal colon tissues of cancer patients were evaluated (Baker et al, 2000; Broll et al, 2001). Vascular endothelial growth factor quantities in skeletal muscle (human vastus lateralis) (Gavin et al, 2004) and rat muscle, for comparison (Zhang et al, 1997) were also evaluated; muscle VEGF content is particularly important since it constitutes close to half the mass of the human body. Vascular endothelial growth factor concentration $\left(\mathrm{pg} \mathrm{ml}^{-1}\right)$ in these tissues was estimated using a protein mass ratio of $160 \mathrm{mg}^{\text {protein }} \mathrm{g}^{-1}$ fatfree tissue and tissue density of $1.06 \mathrm{~g}_{\text {tissue }} \mathrm{ml}^{-1}$ (Lentner et al, 1981).

Vascular endothelial growth factor concentration in normal colon tissues and skeletal muscle ranged between 27.3 and $1500 \mathrm{pg} \mathrm{mg}^{-1}$ protein or 4630 and $254400 \mathrm{pg} \mathrm{ml}^{-1}$ tissue. The total body mass of VEGF can be evaluated using the above data, the body mass of a $30-39$-year-old male $(78 \mathrm{~kg})$, the volume of blood (5l) and the density of blood $\left(1060 \mathrm{~kg} \mathrm{~m}^{-3}\right)$. Assuming that the body consisted only of tissue and blood, we estimated the total VEGF to be between 318 and $17448 \mu \mathrm{g}$.

Vascular endothelial growth factor level in other tissues in rats have been reported in units of $\mathrm{pg} \mathrm{mg}^{-1}$ tissue (Eccles, 2001). Assuming human tissue concentrations similar to these rat concentrations, and using the mass of human organs (Lentner et al, 1981), the total quantity of VEGF in each organ was predicted as $1.8 \mu \mathrm{g}$ in heart, $6.7 \mu \mathrm{g}$ in liver, $30.6 \mu \mathrm{g}$ in lungs, $2.4 \mu \mathrm{g}$ in kidney and $14.6 \mu \mathrm{g}$ in brain. It thus appears that, of the healthy tissues, skeletal muscle contains the most VEGF.

Compared to the total mass of VEGF in the human body, tumour contributes to a relatively small percentage of VEGF $(0.03-2 \%$ for $100 \mathrm{~g}$ tumour, $0.3-16 \%$ for $1 \mathrm{~kg}$ tumour). This may indicate that VEGF is more readily compartmentalised in blood and muscle. Further research will be needed to determine how VEGF is concentrated and transported in each of the compartments of the body.

Free VEGF concentration in healthy and tumour tissues The concentration of free (unbound) VEGF in the interstitial space of human breast tumour and muscle vastus lateralis have been measured using microdialysis. For both tissues, this concentration is in the range of 0.5-1.5 pM (Dabrosin et al, 2002, 2003; Hoffner et al, 2003), or 23-68 $\mathrm{pg} \mathrm{ml}^{-1}$ interstitial space, or $1.6-4.8 \mathrm{pg} \mathrm{ml}^{-1}$ tissue (skeletal muscle), $13.3-39.4 \mathrm{pg} \mathrm{ml}^{-1}$ tissue (breast tumour). Note that the extracellular concentration is similar to the plasma concentration (Figure 3A), suggesting that plasma VEGF and interstitial VEGF are close to being at equilibrium as VEGF moves across the endothelial barrier of the vasculature. Our computational models of VEGF transport in vivo predict that this free VEGF accounts for approximately $1 \%$ of the total extracellular VEGF in the tissue (extracellular VEGF comprises free, extracellular matrix-bound and cell surface receptor-bound) (Mac Gabhann and Popel, 2007). Thus, there is approximately 160$480 \mathrm{pg} \mathrm{ml}^{-1}$ tissue extracellular VEGF in the muscle, or 5.1-15.2 $\mu \mathrm{g}$ in total. This suggests that the remaining (i.e., most of VEGF in the body-approximately $8000 \mu \mathrm{g}$ in skeletal muscle alone, based on concentrations in human vastus lateralis, Gavin et al, 2004) is located intracellularly.

Other VEGF measurements Elevated VEGF is also noted in other angiogenic environments. For example, in wound healing, VEGF concentration in the wound fluid is several fold the plasma or 
serum concentration (Hormbrey et al, 2003; Karayiannakis et al, 2003; Wu et al, 2003; Di Vita et al, 2006). In bone marrow fluid, VEGF levels increase from 1.5 to $4 \mathrm{pm}$ in acute leukaemia patients (Ye et al, 2003).

Vascular endothelial growth factor levels have also been reported in cancer-associated effusions. Vascular endothelial growth factor concentrations in pleural effusions is about three times higher in cancer patients (of various types of cancer) than in healthy subjects (cancer: $2929 \mathrm{pg} \mathrm{ml}^{-1}$, healthy: $930 \mathrm{pg} \mathrm{ml}^{-1}$ ) (Kraft et al, 1999; Thickett et al, 1999; Yanagawa et al, 1999; Matsuyama et al, 2000; Kishiro et al, 2002). In peritoneal effusions, VEGF values increases from about 20 to $31 \mathrm{pmoll}^{-1}$ in cancer patients (of various types of cancer) (Yeo et al, 1993). In these two types of effusions, multiple types of cancer patients are involved (Supplementary Table S3, Online Supplement). In pericardial effusions, lung cancer VEGF levels are about 40-fold the healthy VEGF level (cancer: $3072 \mathrm{pg} \mathrm{ml}^{-1}$, control: $81 \mathrm{pg} \mathrm{ml}^{-1}$ ) (Matsuyama et al, 2000).

Vascular endothelial growth factor secreted from various tissues will eventually be cleared by the kidney. Urine VEGF values have been reported to be higher in cancer patients when compared to healthy controls (Eisen et al, 2000; Bok et al, 2001). Renal clearance of VEGF could be responsible for changing VEGF levels in the blood compartment. Future mechanistic studies should delineate whether increased VEGF in plasma of cancer patients is caused by the increased VEGF secretion by tumour and bone marrow cells, or by the altered rates of VEGF clearance from the kidneys.

\section{REFERENCES}

Adams J, Carder PJ, Downey S, Forbes MA, MacLennan K, Allgar V, Kaufman S, Hallam S, Bicknell R, Walker JJ, Cairnduff F, Selby PJ, Perren TJ, Lansdown M, Banks RE (2000) Vascular endothelial growth factor (VEGF) in breast cancer: comparison of plasma, serum, and tissue VEGF and microvessel density and effects of tamoxifen. Cancer Res 60: 2898-2905

Baker EA, Bergin FG, Leaper DJ (2000) Plasminogen activator system, vascular endothelial growth factor, and colorectal cancer progression. Mol Pathol 53: 307-312

Bando H, Weich HA, Brokelmann M, Horiguchi S, Funata N, Ogawa T, Toi M (2005) Association between intratumoral free and total VEGF, soluble VEGFR-1, VEGFR-2 and prognosis in breast cancer. Br J Cancer 92: 553 - 561

Bauer KS, Figg WD, Hamilton JM, Jones EC, Premkumar A, Steinberg SM, Dyer V, Linehan WM, Pluda JM, Reed E (1999) A pharmacokinetically guided Phase II study of carboxyamido-triazole in androgen-independent prostate cancer. Clin Cancer Res 5: 2324-2329

Bhujwalla ZM, Artemov D, Natarajan K, Ackerstaff E, Solaiyappan M (2001) Vascular differences detected by MRI for metastatic vs nonmetastatic breast and prostate cancer xenografts. Neoplasia 3: $143-153$

Bok RA, Halabi S, Fei DT, Rodriquez CR, Hayes DF, Vogelzang NJ, Kantoff P, Shuman MA, Small EJ (2001) Vascular endothelial growth factor and basic fibroblast growth factor urine levels as predictors of outcome in hormone-refractory prostate cancer patients: a cancer and leukemia group B study. Cancer Res 61: 2533-2536

Broll R, Erdmann H, Duchrow M, Oevermann E, Schwandner O, Markert U, Bruch HP, Windhovel U (2001) Vascular endothelial growth factor (VEGF) - a valuable serum tumour marker in patients with colorectal cancer? Eur J Surg Oncol 27: 37-42

Caine GJ, Blann AD, Stonelake PS, Ryan P, Lip GY (2003) Plasma angiopoietin-1, angiopoietin-2 and Tie-2 in breast and prostate cancer: a comparison with VEGF and Flt-1. Eur J Clin Invest 33: 883-890

Caine GJ, Lip GY, Blann AD (2004) Platelet-derived VEGF, Flt-1, angiopoietin-1 and P-selectin in breast and prostate cancer: further evidence for a role of platelets in tumour angiogenesis. Ann Med 36: $273-277$

Calvo A, Xiao N, Kang J, Best CJ, Leiva I, Emmert-Buck MR, Jorcyk C, Green JE (2002) Alterations in gene expression profiles during prostate cancer progression: functional correlations to tumorigenicity and down-

\section{CONCLUSION}

Our results provide an integrative analysis of VEGF levels in various compartments of the body in cancer patients and address important issues in VEGF data interpretation. Conclusions drawn from VEGF values in different cancer types were consistent. Within the blood compartment, VEGF is mostly concentrated in the platelets, although a significant portion was localised in leukocytes during cancer development. Large quantities of VEGF were reported in tumour and skeletal muscle, the latter of which suggested an intracellular VEGF source.

The most surprising result of this analysis is that even in cancer, tumours are not the largest source of VEGF in the body. Other tissues, and in particular skeletal muscle, appear to contain a large reservoir of VEGF, and this should be a consideration in the design of cancer therapeutics. For example, the systemic administration of anti-VEGF antibodies may have to overcome the effects of a large non-tumour-derived VEGF reservoir.

\section{ACKNOWLEDGEMENTS}

We thank Dr R Pili, Dr HMW Verheul and Dr HJ Hammers for useful discussions. This study was supported in part by NIH Grants HL079653 and HL087351.

Supplementary Information accompanies the paper on British Journal of Cancer website (http://www.nature.com/bjc)

regulation of selenoprotein-P in mouse and human tumors. Cancer Res 62: $5325-5335$

Chin KF, Greenman J, Gardiner E, Kumar H, Topping K, Monson J (2000) Pre-operative serum vascular endothelial growth factor can select patients for adjuvant treatment after curative resection in colorectal cancer. Br I Cancer 83: 1425-1431

Cianchi F, Cortesini C, Fantappie O, Messerini L, Sardi I, Lasagna N, Perna F, Fabbroni V, Di Felice A, Perigli G, Mazzanti R, Masini E (2004) Cyclooxygenase-2 activation mediates the proangiogenic effect of nitric oxide in colorectal cancer. Clin Cancer Res 10: 2694-2704

Colleoni M, Rocca A, Sandri MT, Zorzino L, Masci G, Nole F, Peruzzotti G, Robertson C, Orlando L, Cinieri S, de BF, Viale G, Goldhirsch A (2002) Low-dose oral methotrexate and cyclophosphamide in metastatic breast cancer: antitumor activity and correlation with vascular endothelial growth factor levels. Ann Oncol 13: 73-80

Dabrosin C, Chen J, Wang L, Thompson LU (2002) Flaxseed inhibits metastasis and decreases extracellular vascular endothelial growth factor in human breast cancer xenografts. Cancer Lett 185: $31-37$

Dabrosin C, Margetts PJ, Gauldie J (2003) Estradiol increases extracellular levels of vascular endothelial growth factor in vivo in murine mammary cancer. Int J Cancer 107: 535-540

Davies MM, Jonas SK, Kaur S, Allen-Mersh TG (2000) Plasma vascular endothelial but not fibroblast growth factor levels correlate with colorectal liver mestastasis vascularity and volume. $\mathrm{Br} \mathrm{J}$ Cancer 82: $1004-1008$

Desruisseau S, Palmari J, Giusti C, Romain S, Martin PM, Berthois Y (2004) Clinical relevance of amphiregulin and VEGF in primary breast cancers. Int J Cancer 111: $733-740$

Di Vita G, Patti R, D’Agostino P, Caruso G, Arcara M, Buscemi S, Bonventre S, Ferlazzo V, Arcoleo F, Cillari E (2006) Cytokines and growth factors in wound drainage fluid from patients undergoing incisional hernia repair. Wound Repair Regen 14: 259-264

Dirix LY, Vermeulen PB, Hubens G, Benoy I, Martin M, De Pooter C, Van Oosterom AT (1996) Serum basic fibroblast growth factor and vascular endothelial growth factor and tumour growth kinetics in advanced colorectal cancer. Ann Oncol 7: $843-848$

Dosquet C, Coudert MC, Lepage E, Cabane J, Richard F (1997) Are angiogenic factors, cytokines, and soluble adhesion molecules prognostic 
factors in patients with renal cell carcinoma? Clin Cancer Res 3: $2451-2458$

Duque JL, Loughlin KR, Adam RM, Kantoff PW, Zurakowski D, Freeman MR (1999) Plasma levels of vascular endothelial growth factor are increased in patients with metastatic prostate cancer. Urology 54: $523-527$

Eatock MM, Schatzlein A, Kaye SB (2000) Tumour vasculature as a target for anticancer therapy. Cancer Treat Rev 26: 191-204

Eccles SA (2001) The role of c-erbB-2/HER2/neu in breast cancer progression and metastasis. J Mammary Gland Biol Neoplasia 6: $393-406$

Eisen T, Boshoff C, Mak I, Sapunar F, Vaughan MM, Pyle L, Johnston SR, Ahern R, Smith IE, Gore ME (2000) Continuous low dose Thalidomide: a phase II study in advanced melanoma, renal cell, ovarian and breast cancer. Br J Cancer 82: $812-817$

Eppenberger U, Kueng W, Schlaeppi JM, Roesel JL, Benz C, Mueller H, Matter A, Zuber M, Luescher K, Litschgi M, Schmitt M, Foekens JA, Eppenberger-Castori S (1998) Markers of tumor angiogenesis and proteolysis independently define high- and low-risk subsets of nodenegative breast cancer patients. J Clin Oncol 16: 3129-3136

Feldman AL, Alexander Jr HR, Bartlett DL, Kranda KC, Miller MS, Costouros NG, Choyke PL, Libutti SK (2001) A prospective analysis of plasma endostatin levels in colorectal cancer patients with liver metastases. Ann Surg Oncol 8: $741-745$

Ferrara N, Davis-Smyth T (1997) The biology of vascular endothelia growth factor. Endocr Rev 18: 4-25

Figg WD, Dahut W, Duray P, Hamilton M, Tompkins A, Steinberg SM, Jones E, Premkumar A, Linehan WM, Floeter MK, Chen CC, Dixon S, Kohler DR, Kruger EA, Gubish E, Pluda JM, Reed E (2001) A randomized phase II trial of thalidomide, an angiogenesis inhibitor, in patients with androgen-independent prostate cancer. Clin Cancer Res 7: 1888-1893

Foekens JA, Peters HA, Grebenchtchikov N, Look MP, Meijer-van Gelder ME, Geurts-Moespot A, van der Kwast TH, Sweep CG, Klijn JG (2001) High tumor levels of vascular endothelial growth factor predict poor response to systemic therapy in advanced breast cancer. Cancer Res 61: $5407-5414$

Folkman J (1995) Seminars in medicine of the Beth Israel Hospital, Boston. Clinical applications of research on angiogenesis. $N$ Engl J Med 333: $1757-1763$

Folkman J (2007) Angiogenesis: an organizing principle for drug discovery? Nat Rev Drug Discov 6: 273 - 286

Gasparini G (2000) Prognostic value of vascular endothelial growth factor in breast cancer. Oncologist 5(Suppl 1): $37-44$

Gavin TP, Robinson CB, Yeager RC, England JA, Nifong LW, Hickner RC (2004) Angiogenic growth factor response to acute systemic exercise in human skeletal muscle. J Appl Physiol 96: 19-24

George DJ, Halabi S, Shepard TF, Vogelzang NJ, Hayes DF, Small EJ, Kantoff PW (2001) Prognostic significance of plasma vascular endothelial growth factor levels in patients with hormone-refractory prostate cancer treated on Cancer and Leukemia Group B 9480. Clin Cancer Res 7: 1932 - 1936

George DJ, Regan MM, Oh WK, Tay MH, Manola J, Decalo N, Duggan S, Dewolf WC, Kantoff PW, Bubley GJ (2004) Radical prostatectomy lowers plasma vascular endothelial growth factor levels in patients with prostate cancer. Urology 63: 327-332

George ML, Eccles SA, Tutton MG, Abulafi AM, Swift RI (2000) Correlation of plasma and serum vascular endothelial growth factor levels with platelet count in colorectal cancer: clinical evidence of platelet scavenging? Clin Cancer Res 6: $3147-3152$

Granato AM, Nanni O, Falcini F, Folli S, Mosconi G, De Paola F, Medri L, Amadori D, Volpi A (2004) Basic fibroblast growth factor and vascula endothelial growth factor serum levels in breast cancer patients and healthy women: useful as diagnostic tools? Breast Cancer Res 6: R38-R45

Haggstrom S, Bergh A, Damber JE (2000) Vascular endothelial growth factor content in metastasizing and nonmetastasizing Dunning prostatic adenocarcinoma. Prostate 45: $42-50$

Haraguchi M, Komuta K, Akashi A, Matsuzaki S, Furui J, Kanematsu T (2002) Elevated IL-8 levels in the drainage vein of resectable Dukes' C colorectal cancer indicate high risk for developing hepatic metastasis. Oncol Rep 9: $159-165$

Heer K, Kumar H, Read JR, Fox JN, Monson JR, Kerin MJ (2001) Serum vascular endothelial growth factor in breast cancer: its relation with cancer type and estrogen receptor status. Clin Cancer Res 7: $3491-3494$

Hoffner L, Nielsen JJ, Langberg H, Hellsten Y (2003) Exercise but not prostanoids enhance levels of vascular endothelial growth factor and other proliferative agents in human skeletal muscle interstitium. J Physiol 550: $217-225$

Hormbrey E, Gillespie P, Turner K, Han C, Roberts A, McGrouther D, Harris AL (2002) A critical review of vascular endothelial growth factor (VEGF) analysis in peripheral blood: is the current literature meaningful? Clin Exp Metastasis 19: 651-663

Hormbrey E, Han C, Roberts A, McGrouther DA, Harris AL (2003) The relationship of human wound vascular endothelial growth factor (VEGF) after breast cancer surgery to circulating VEGF and angiogenesis. Clin Cancer Res 9: $4332-4339$

Huss WJ, Hanrahan CF, Barrios RJ, Simons JW, Greenberg NM (2001) Angiogenesis and prostate cancer: identification of a molecular progression switch. Cancer Res 61: 2736-2743

Hyodo I, Doi T, Endo H, Hosokawa Y, Nishikawa Y, Tanimizu M, Jinno K, Kotani Y (1998) Clinical significance of plasma vascular endothelial growth factor in gastrointestinal cancer. Eur J Cancer 34: $2041-2045$

Jacobsen J, Grankvist K, Rasmuson T, Ljungberg B (2002) Prognostic importance of serum vascular endothelial growth factor in relation to platelet and leukocyte counts in human renal cell carcinoma. Eur J Cancer Prev 11: 245-252

Jemal A, Murray T, Ward E, Samuels A, Tiwari RC, Ghafoor A, Feuer EJ, Thun MJ (2005) Cancer statistics, 2005. CA Cancer J Clin 55: 10-30

Jones A, Fujiyama C, Turner K, Fuggle S, Cranston D, Bicknell R, Harris AL (2000) Elevated serum vascular endothelial growth factor in patients with hormone-escaped prostate cancer. BJU Int 85: 276-280

Joseph IB, Nelson JB, Denmeade SR, Isaacs JT (1997) Androgens regulate vascular endothelial growth factor content in normal and malignant prostatic tissue. Clin Cancer Res 3: $2507-2511$

Karayiannakis AJ, Syrigos KN, Zbar A, Baibas N, Polychronidis A, Simopoulos C, Karatzas G (2002) Clinical significance of preoperative serum vascular endothelial growth factor levels in patients with colorectal cancer and the effect of tumor surgery. Surgery 131: 548-555

Karayiannakis AJ, Zbar A, Polychronidis A, Simopoulos C (2003) Serum and drainage fluid vascular endothelial growth factor levels in early surgical wounds. Eur Surg Res 35: $492-496$

Kaushal V, Mukunyadzi P, Dennis RA, Siegel ER, Johnson DE, Kohli M (2005) Stage-specific characterization of the vascular endothelial growth factor axis in prostate cancer: expression of lymphangiogenic markers is associated with advanced-stage disease. Clin Cancer Res 11: 584-593

Kelavkar UP, Nixon JB, Cohen C, Dillehay D, Eling TE, Badr KF (2001) Overexpression of 15-lipoxygenase-1 in PC-3 human prostate cancer cells increases tumorigenesis. Carcinogenesis 22: 1765-1773

Kishiro I, Kato S, Fuse D, Yoshida T, Machida S, Kaneko N (2002) Clinical significance of vascular endothelial growth factor in patients with primary lung cancer. Respirology 7: 93-98

Kohli M, Kaushal V, Spencer HJ, Mehta P (2003) Prospective study of circulating angiogenic markers in prostate-specific antigen (PSA)-stable and PSA-progressive hormone-sensitive advanced prostate cancer. Urology 61: 765-769

Kraft A, Weindel K, Ochs A, Marth C, Zmija J, Schumacher P, Unger C, Marme D, Gastl G (1999) Vascular endothelial growth factor in the sera and effusions of patients with malignant and nonmalignant disease. Cancer 85: $178-187$

Kumar H, Heer K, Lee PW, Duthie GS, MacDonald AW, Greenman J, Kerin MJ, Monson JR (1998) Preoperative serum vascular endothelial growth factor can predict stage in colorectal cancer. Clin Cancer Res 4: $1279-1285$

Kusumanto YH, Dam WA, Hospers GA, Meijer C, Mulder NH (2003) Platelets and granulocytes, in particular the neutrophils, form important compartments for circulating vascular endothelial growth factor. Angiogenesis 6: 283-287

Lentner C, Lentner C, Wink A (1981) Geigy Scientific Tables, Volume 1. West Caldwell, New Jersey 07006: Medical Education Division, CibaGeigy Corporation

Lentner C, Lentner C, Wink A (1984) Geigy Scientific Tables, Volume 3. West Caldwell, New Jersey 07006: Medical Education Division, CibaGeigy Corporation

Li H, Kantoff PW, Ma J, Stampfer MJ, George DJ (2005) Prediagnostic plasma vascular endothelial growth factor levels and risk of prostate cancer. Cancer Epidemiol Biomarkers Prev 14: $1557-1561$

Liu XH, Kirschenbaum A, Yao S, Stearns ME, Holland JF, Claffey K, Levine AC (1999) Upregulation of vascular endothelial growth factor by cobalt chloride-simulated hypoxia is mediated by persistent induction of cyclooxygenase- 2 in a metastatic human prostate cancer cell line. Clin Exp Metastasis 17: 687-694 
Ljungberg B, Jacobsen J, Haggstrom-Rudolfssson S, Rasmuson T, Lindh G, Grankvist K (2003) Tumour vascular endothelial growth factor (VEGF) mRNA in relation to serum VEGF protein levels and tumour progression in human renal cell carcinoma. Urol Res 31: 335-340

Mabjeesh NJ, Willard MT, Frederickson CE, Zhong H, Simons JW (2003) Androgens stimulate hypoxia-inducible factor 1 activation via autocrine loop of tyrosine kinase receptor/phosphatidylinositol $3^{\prime}$-kinase/protein kinase B in prostate cancer cells. Clin Cancer Res 9: 2416-2425

Mac Gabhann F, Ji JW, Popel AS (2006) Computational model of vascular endothelial growth factor spatial distribution in muscle and proangiogenic cell therapy. PLoS Comput Biol 2: e127

Mac Gabhann F, Popel AS (2006) Targeting neuropilin-1 to inhibit VEGF signaling in cancer: comparison of therapeutic approaches. PLoS Comput Biol 2: e180

Mac Gabhann F, Popel AS (2007) Interactions of VEGF isoforms with VEGFR-1, VEGFR-2, and neuropilin in vivo: a computational model of human skeletal muscle. Am J Physiol Heart Circ Physiol 292: H459-H474

Manders P, Beex LV, Tjan-Heijnen VC, Span PN, Sweep CG (2003) Vascular endothelial growth factor is associated with the efficacy of endocrine therapy in patients with advanced breast carcinoma. Cancer 98: $2125-2132$

Matsuyama W, Hashiguchi T, Mizoguchi A, Iwami F, Kawabata M, Arimura K, Osame M (2000) Serum levels of vascular endothelial growth factor dependent on the stage progression of lung cancer. Chest 118: 948-951

May KM, Vogt A, Bachas LG, Anderson KW (2005) Vascular endothelial growth factor as a biomarker for the early detection of cancer using a whole cell-based biosensor. Anal Bioanal Chem 382: 1010-1016

Mohle R, Green D, Moore MA, Nachman RL, Rafii S (1997) Constitutive production and thrombin-induced release of vascular endothelial growth factor by human megakaryocytes and platelets. Proc Natl Acad Sci USA 94: $663-668$

Obermair A, Kucera E, Mayerhofer K, Speiser P, Seifert M, Czerwenka K, Kaider A, Leodolter S, Kainz C, Zeillinger R (1997) Vascular endothelial growth factor (VEGF) in human breast cancer: correlation with diseasefree survival. Int J Cancer 74: 455-458

O'Riain SC, Buggy DJ, Kerin MJ, Watson RW, Moriarty DC (2005) Inhibition of the stress response to breast cancer surgery by regional anesthesia and analgesia does not affect vascular endothelial growth factor and prostaglandin E2. Anesth Analg 100: 244-249

Poon RT, Ng IO, Lau C, Zhu LX, Yu WC, Lo CM, Fan ST, Wong J (2001) Serum vascular endothelial growth factor predicts venous invasion in hepatocellular carcinoma: a prospective study. Ann Surg 233: 227-235

Salgado R, Vermeulen PB, Benoy I, Weytjens R, Huget P, Van Marck E, Dirix LY (1999) Platelet number and interleukin-6 correlate with VEGF but not with bFGF serum levels of advanced cancer patients. Br J Cancer 80: $892-897$

Salven P, Manpaa H, Orpana A, Alitalo K, Joensuu H (1997) Serum vascular endothelial growth factor is often elevated in disseminated cancer. Clin Cancer Res 3: 647-651

Salven P, Orpana A, Joensuu H (1999a) Leukocytes and platelets of patients with cancer contain high levels of vascular endothelial growth factor. Clin Cancer Res 5: 487-491

Salven P, Perhoniemi V, Tykka H, Maenpaa H, Joensuu H (1999b) Serum VEGF levels in women with a benign breast tumor or breast cancer. Breast Cancer Res Treat 53: $161-166$

Sancak B, Coskun U, Gunel N, Onuk E, Cihan A, Karamercan A, Yildirim Y, Ozkan S (2004) No association between serum levels of insulin-like growth factor-I, vascular endothelial growth factor, prolactin and clinicopathological characteristics of breast carcinoma after surgery. Intern Med J 34: 310-315

Sato K, Tsuchiya N, Sasaki R, Shimoda N, Satoh S, Ogawa O, Kato T (1999) Increased serum levels of vascular endothelial growth factor in patients with renal cell carcinoma. Jpn J Cancer Res 90: 874-879

Shibuya M, Claesson-Welsh L (2006) Signal transduction by VEGF receptors in regulation of angiogenesis and lymphangiogenesis. Exp Cell Res 312: $549-560$

Singh RP, Sharma G, Mallikarjuna GU, Dhanalakshmi S, Agarwal C, Agarwal R (2004) In vivo suppression of hormone-refractory prostate cancer growth by inositol hexaphosphate: induction of insulin-like growth factor binding protein-3 and inhibition of vascular endothelial growth factor. Clin Cancer Res 10: 244-250
Stockhammer G, Obwegeser A, Kostron H, Schumacher P, Muigg A, Felber S, Maier H, Slavc I, Gunsilius E, Gastl G (2000) Vascular endothelial growth factor (VEGF) is elevated in brain tumor cysts and correlates with tumor progression. Acta Neuropathol (Berl) 100: $101-105$

Tabone MD, Landman-Parker J, Arcil B, Coudert MC, Gerota I, Benbunan M, Leverger G, Dosquet C (2001) Are basic fibroblast growth factor and vascular endothelial growth factor prognostic indicators in pediatric patients with malignant solid tumors? Clin Cancer Res 7: 538- 543

Tempfer C, Obermair A, Hefler L, Haeusler G, Gitsch G, Kainz C (1998) Vascular endothelial growth factor serum concentrations in ovarian cancer. Obstet Gynecol 92: 360-363

Thickett DR, Armstrong L, Millar AB (1999) Vascular endothelial growth factor (VEGF) in inflammatory and malignant pleural effusions. Thorax 54: $707-710$

Toi M, Bando H, Ogawa T, Muta M, Hornig C, Weich HA (2002) Significance of vascular endothelial growth factor (VEGF)/soluble VEGF receptor-1 relationship in breast cancer. Int J Cancer 98: 14-18

Tortora G, Melisi D, Ciardiello F (2004) Angiogenesis: a target for cancer therapy. Curr Pharm Des 10: 11-26

Uzzan B, Nicolas P, Cucherat M, Perret GY (2004) Microvessel density as a prognostic factor in women with breast cancer: a systematic review of the literature and meta-analysis. Cancer Res 64: 2941-2955

Verheul HM, Hoekman K, Luykx-de Bakker S, Eekman CA, Folman CC, Broxterman HJ, Pinedo HM (1997) Platelet: transporter of vascular endothelial growth factor. Clin Cancer Res 3: 2187-2190

Verheul HM, Pinedo HM (1998) Tumor growth: a putative role for platelets? Oncologist 3: II

Viac J, Schmitt D, Claudy A (1998) Circulating vascular endothelial growth factor (VEGF) is not a prognostic indicator in malignant melanoma. Cancer Lett 125: 35-38

Werther K, Bulow S, Hesselfeldt P, Jespersen NF, Svendsen MN, Nielsen HJ (2002a) VEGF concentrations in tumour arteries and veins from patients with rectal cancer. Apmis 110: 646-650

Werther K, Christensen IJ, Nielsen HJ (2002b) Determination of vascular endothelial growth factor (VEGF) in circulating blood: significance of VEGF in various leucocytes and platelets. Scand J Clin Lab Invest 62: $343-350$

Werther K, Sorensen S, Christensen IJ, Nielsen HJ (2003) Circulating vascular endothelial growth factor six months after primary surgery as a prognostic marker in patients with colorectal cancer. Acta Oncol 42: $837-845$

Wu FP, Hoekman K, Meijer S, Cuesta MA (2003) VEGF and endostatin levels in wound fluid and plasma after breast surgery. Angiogenesis 6: $255-257$

Yamamoto Y, Toi M, Kondo S, Matsumoto T, Suzuki H, Kitamura M, Tsuruta K, Taniguchi T, Okamoto A, Mori T, Yoshida M, Ikeda T, Tominaga T (1996) Concentrations of vascular endothelial growth factor in the sera of normal controls and cancer patients. Clin Cancer Res 2: $821-826$

Yanagawa H, Takeuchi E, Suzuki Y, Ohmoto Y, Bando H, Sone S (1999) Vascular endothelial growth factor in malignant pleural effusion associated with lung cancer. Cancer Immunol Immunother 48: 396-400

Ye XJ, Wang LJ, Lin MF, Ding W (2003) [The clinical significance of angiogenesis in the bone marrow of acute leukemia patients]. Zhonghua Nei Ke Za Zhi 42: 486-489

Yeo KT, Wang HH, Nagy JA, Sioussat TM, Ledbetter SR, Hoogewerf AJ, Zhou Y, Masse EM, Senger DR, Dvorak HF et al (1993) Vascular permeability factor (vascular endothelial growth factor) in guinea pig and human tumor and inflammatory effusions. Cancer Res 53: $2912-2918$

Yoshikawa T, Tsuburaya A, Kobayashi O, Sairenji M, Motohashi H, Yanoma S, Noguchi Y (2000) Plasma concentrations of VEGF and bFGF in patients with gastric carcinoma. Cancer Lett 153: 7-12

Zhang QX, Magovern CJ, Mack CA, Budenbender KT, Ko W, Rosengart TK (1997) Vascular endothelial growth factor is the major angiogenic factor in omentum: mechanism of the omentum-mediated angiogenesis. J Surg Res 67: $147-154$

Zhao J, Yan F, Ju H, Tang J, Qin J (2004) Correlation between serum vascular endothelial growth factor and endostatin levels in patients with breast cancer. Cancer Lett 204: 87-95 